\title{
Rethinking militarism as ideology: the critique of violence after security
}

\section{Introduction}

Militarism is best conceived of as an ideological phenomenon. This is not only the most coherent way to understand militarism, but also the best way to consolidate the advantages of the concept over existing approaches to the study of violence ${ }^{1}$ which prioritise the notion of security. Current approaches to militarism tend to be sceptical of definitions which emphasise ideology. This is normally because of a desire to move beyond studying a narrow realm of ideas artificially separated from wider social practices and beyond straightforward cases in which violence is overtly glorified. If this is indeed what conceiving of militarism as ideology means, it should be rightly rejected. In my view, however, such criticisms misrepresent the effects of viewing militarism as ideological and invoke a caricatured and outmoded concept of ideology which few would defend today. In fact, properly undertaken, the critique of ideology has a great deal to offer the study of militarism, and need not suffer from the shortcomings identified above. By revisiting Althusser's classic work on ideology and combining it with more recent scholarship drawing on psychoanalysis, I argue that the perceived disadvantages of an ideological concept of militarism are illusory. Instead, I show that rethinking militarism as ideology complements rather than contradicts existing studies of militarism and moreover can offer a great deal to the wider study of violence.

Thus far, the study of violence in International Relations has been dominated by the concept of security, which - notwithstanding the attempts of an array of "critical" scholars - continues to suffer from a number of analytical and political shortcomings. A focus on militarism as ideology can help to surmount these difficulties by re-centring the task of anti-militarist critique. A critical concept of militarism forces an examination not just of the extent to which certain political issues are made military concerns but more precisely of the way in which participation in war and military activity are made desirable through ideology. This offers a much surer starting point for an ethico-political critique of violence, including of justifications for the use of force presented within Critical Security Studies itself. 
I begin the article by discussing how the relationship between militarism and ideology has previously been approached, highlighting the problems with these perspectives. Secondly, I reconstruct a theory of ideology which is appropriate for the study of militarism, drawing on Althusser and psychoanalytic approaches. Thirdly, I discuss the difficulties encountered by Critical Security Studies in conducting a critique of violence and how this endeavour can be more satisfactorily framed and pursued when attention is paid to militarism as ideology.

\section{I: Militarism: sociological, not ideological?}

Surveying its place in the discipline of IR Stavrianakis and Selby identify five possible definitions of the concept of militarism - as ideology, as a behavioural phenomenon, as military build-up, as a set of institutional relationships, as a sociological process - and argue that the last of these is the most productive (Stavrianakis and Selby, 2013: 11-16). Following the arguments of Martin Shaw, they claim that "it is reductionist and limiting to essentialise militarism as ideology" (2013: 12), since this risks foreclosing the study of a broader array of non-ideational phenomena. There is no doubt that adopting a sociological perspective on militarism has been an enormously fruitful analytical move (see also Mabee and Vucetic, this issue). It has produced a range of studies showing the multiple and subtle ways in which militarism pervades social structures and subjectivities, reshaping culture, political economy, and identities. What is less clear, however, is why this should necessarily preclude a definition centred on ideology.

One of the earliest definitions of militarism in ideological terms, still widely cited today, was given by Alfred Vagts in his History of Militarism. Vagts defined militarism as follows:

"Militarism is... not the opposite of pacifism; its true counterpart is civilianism. Love of war, bellicosity, is a counterpart of the love of peace, pacifism; but militarism is more and sometimes less, than the love of war. It covers every system of thinking and valuing in every complex of feelings which rank military institutions and ways above the ways of civilian life, carrying military mentality and modes of acting and decision into the civilian sphere." (Vagts, 1959: 17) 
Critics of an ideological understanding of militarism often cite this passage as evidence of a narrow definition focussed on a set of ideas favouring war and the military. Shaw, for example, glosses the last sentence to mean belief systems "“glorifying' military power" (2013: 19), even though this is not what Vagts wrote. Reading the full passage, it seems clear that the crux of Vagts' concept is that militarism implies, not love of war, but first and foremost the state of being in thrall to war, of being influenced by and caught up in military ways. In this view, militarism can be a highly ambivalent and subtle phenomenon, rather than simply a voluntarist glorification of war.

Shaw also criticises Vagts for focussing too narrowly on ideas, rather than questions of social structure. For Shaw, militarism denotes "the penetration of social relations in general by military relations" (2013: 20), measuring the "influence of military organisation and values on social structure" (Shaw, 1991: 4-5). Shaw therefore claims to extend Vagts' original understanding of militarism to a wider range of social practices. He criticises an emphasis on ideology and instead prefers Michael Mann's definition of militarism as “a set of attitudes and social practices which regards war and the preparation for war as a normal and desirable social activity" (Mann, 1987: 35). Shaw writes:

"It is sociologically unenlightening to restrict the meaning to ideology: the core idea is the 'carrying' of military forms into the civilian sphere, and this is not merely a matter of 'mentality' or 'attitudes' but (as Mann notes) of 'social practices'. Moreover the military forms which are carried may not necessarily 'rank military institutions and ways above the prevailing attitudes of civilian life', let alone 'glorify' war in a simple sense.” (2013: 19-20)

Valuable as this insistence on the importance of social practice surely is, it still misrepresents Vagts' original position. Not only does Shaw once again elide the important distinction which Vagts made between "love of war" and militarism (by inserting the term "glorify" in inverted commas without a citation), he also ignores the fact that Vagts quite clearly speaks of "carrying military mentality and modes of acting into the civilian sphere [my emphasis]". Furthermore, it is not clear how Shaw can define militarism as "the penetration of social relations in general by military relations" without agreeing that this necessitates "rank[ing] military institutions and ways above the prevailing attitudes 
of civilian life". Surely the penetration of social relations by military relations has to imply giving priority to military relations, even if the priority given is not always enthusiastic (something Vagts never claimed). But instead, Shaw has proposed a sharp distinction:

"The ideological impact of war-preparation is only one part of its influence on society. We may distinguish therefore between militarism, in general, and militarist ideologies, which are belief systems that give a high value to military activities." (Shaw, 1991: 12)

Yet there is a danger that this distinction reinstates precisely the separation between ideas and social practice which Shaw wishes to avoid. It risks invoking an outmoded concept of ideology which reduces it to an epiphenomenal set of beliefs with only a contingent relationship to material reality. As I argue below, such a characterisation is in fact completely inconsistent with the way that this relationship is understood by the critique of ideology.

It may be, however, that the desire to avoid an ideological critique of militarism is not truly grounded in an analytic rationale. The political stakes of this distinction between "militarism in general" and “militarist ideologies" are made clear in Shaw's additional reasoning for his position:

"[An] advantage of this approach is that it pre-empts the political abuse to which the ideological definition easily lends itself. Invariably, "their" war-making and war-preparation is aggressive, destructive, glorifies war and is "militarist", "ours" is defensive, humanitarian, does not glorify war and is not "militarist". The deeper sociological definition removes the simple negative connotation and in principle allows that arguments justifying militarism and militarisation may be plausible, although it retains critical potential. It is possible to use it in a coherent socialscientific manner, in ways which tie it neither to a particular political critique nor to the analysis of the past." (2013: 20)

For Shaw, then, describing something as militarist is neither a value judgment nor a political verdict: "Unless [...] one is a strict pacifist, militarism is not a matter of good or bad, but of how far military organisation and values (which sometimes may be justified and necessary) impinge on social structure" (Shaw, 1991: 12). 
The first problem with this position is that it excludes the possibility of a non-pacifist anti-militarism. Its logical extension is that one cannot oppose militarism - even its most egregious examples without endorsing the view that all war and violence is unjustifiable. While this may accurately describe the perspective of some, and especially some feminist, strains of anti-militarism, this clearly does not exhaust the possibilities for the critique of political violence (on this point see Hutchings, 2007). In this paper, by contrast, I begin to outline the possibility of such a non-pacifist antimilitarism. A more major difficulty with Shaw's stance is that it abdicates from addressing key ethical and political questions regarding violence at all. This stance is not unique among scholars of militarism. For example, Stavrianakis and Selby, while they understand much of the work in their edited volume as guided by "an implicit anti-militarism", nevertheless state that "the research agenda we propose is fundamentally sociological and analytic, not 'anti-militarist'" (Stavrianakis and Selby, 2013: 16; see also Skjelsbaek, 1980: 99). It is, however, important to note that there are scholars, not to mention countless activists, who do consider themselves explicitly anti-militarist (Cockburn, 2012; Rossdale, 2015). Indeed, I will argue that if scholars are to address vital ethico-political questions concerning violence, an explicit orientation towards anti-militarist critique is an important step to take. In fact, I would suggest that one of the clearest advantages of adopting the concept of militarism is its pejorative, critical connotation. In marked contrast to "security", which is a language primarily developed by and borrowed from the state, "militarism" builds on political and rhetorical resources developed by anti-militarist social movements (cf. Rossdale, 2010). As a result of these struggles, whereas many practitioners are quite comfortable being identified as security actors (even if this appellation is used with critical intent), far fewer are comfortable being identified with militarism.

\section{II: Militarism and the critique of ideology}

Part of the difficulty in defining militarism as ideology is that the term has several meanings. A common understanding of ideology is as a set of beliefs or attitudes, perhaps even an elaborate doctrine or body of principles, which make up a worldview. Militarism as ideology from this perspective would be a more or less explicit set of tenets which held that war and the military were to be valued above other things. Such an understanding of militarism as ideology is indeed hopelessly 
narrow, ignoring the role of social structures and practices. It would also risk explanatory idealism, imputing to a set of ideas, somehow distinct from material reality, a potentially independent motor force in bringing about war.

Fortunately, this is not the way in which the concept is understood by the critique of ideology. At least since Althusser (1971), theorists have had a concept of ideology which necessarily includes "ideological apparatuses", i.e. sets of institutions and practices which produce and sustain ideology. Furthermore, for Althusser, the purpose of these apparatuses is the reproduction of the relations of production and thus the material domination of one class over another. As such, ideology has a material existence, and cannot exist independently either from the concrete apparatuses which make it possible or from the material relations of production it reproduces. The materialism of Althusser's analysis is mostly famously illustrated in his description of Pascal's view of the power of prayer to generate faith: "Kneel down, move your lips in prayer, and you will believe" (1971: 168). In this example, it is the material, corporeal act of prayer - set in the institution of the Church - which produces the belief in the subject. Therefore, while for Althusser ideology "represents the imaginary relationship of individuals to their real conditions of existence" (1971: 162), it cannot do so independently of "a material ideological apparatus, prescribing material practices governed by a material ritual, which practices exist in the material actions of a subject acting in all consciousness according to his belief" (1971: 170).

Indeed, Althusser seeks to remove an emphasis on "ideas" from his discussion of ideology, preferring instead to concentrate on the way in which material ideological practices "interpellate individuals as subjects" with defined self-understandings in the given social structure (1971: 160-165). In this sense ideology is reducible neither to the beliefs those subjects hold nor to the material practices which instantiate those beliefs. Rather, ideology is a structural relationship between social practices and the individuals who participate in them, which works by producing those individuals as subjects. This emphasis on subject formation as integral to ideology has also been taken up by theorists working in the tradition of Lacanian psychoanalysis, beginning with the Cahiers pour l'Analyse in the 1960s (Hallward and Peden, 2012) and continuing most notably in the work of Slavoj Žižek (Žižek, 2008a, 
2008b, 2008c, 2012). For psychoanalysis, the question of desire is fundamental: the key process to be understood is the way that ideology becomes desirable, at a deep unconscious level, for the subjects it interpellates. Together, these studies allow for an understanding of ideology which posits its centrality to the functioning of social life, and in particular to the formation of desiring subjects, and therefore as an object of critique.

My argument is that this is how we should think of militarism. As a sociological phenomenon, militarism is inherently rather than contingently ideological: it always includes an ideological legitimation of violence. It is a structural relationship between military practices and the individuals who participate in them, which takes effect by interpellating those individuals as subjects who desire war and military activity. As I have already made clear, this desire need not take the form of an enthusiastic love. It can be a much more ambivalent, even involuntary or unconscious, phenomenon which manifests itself in a variety of ways. Existing scholarship in Critical Military Studies has already done a great deal to demonstrate this: militarist subjects can be made to desire war and military activity through gender relations (e.g. Altınay, 2004; Conway, 2012; Enloe, 2000; Segal, 2008; Sjoberg and Via, 2010), through corporeal activity (e.g. Higate, 2012; McSorley, 2013, 2016; Sasson-Levy, 2008), through the manipulation of class and/or racial identities (e.g. Basham, 2016; Sasson-Levy, 2003), or even through the eroticisation of submission to the state (Crane-Seeber, 2016). All of these practices are ideological: they perform the function of making war and military activity desirable to these subjects, and they are no less material or social for that. Moreover, participation in organised political violence can be broadly conceived here: it of course includes the work of soldiers, but it also encompasses the contribution of a much wider range of actors in economic, caring, or supporting roles, and can even be extended to passive acceptance or acquiescence in war. In each of these cases, subjects are formed with personal, economic, social, and/or psychic investments in military activity.

What ideology critique can most significantly contribute to existing approaches, however, is precisely that it foregrounds the task of critique. According to sociological understandings, militarism describes the penetration by military relations of social relations in general. This can be in greater or 
lesser degrees; an advance in this penetration is described as militarisation, a retreat as demilitarisation (Shaw, 2013: 20). Yet this generates a question: should all participation in organised political violence therefore be considered "militarism", no matter what its scale or objectives? As shown above, a purely sociological perspective abdicates from answering this question, considering it too "political". Even if we are comfortable with this abdication, however, what then is the advantage of "militarism" over the concept of "war" or "political violence"? All wars require the penetration of social relations by military relations, no matter in what degree, as scholars of Critical War Studies have shown (Barkawi and Brighton, 2011; Barkawi, 2011; Sylvester, 2012). If the term militarism is to imply something distinctive, it must surely be describing a particular kind of penetration by military relations of social relations, one that is not necessarily equally present in all cases. In my view, the particular kind of penetration being implied by the term militarism is an ideological penetration. Furthermore, the use of the term "militarism" implies a critical ethico-political intervention, designed to identify this ideological penetration as problematic and to disrupt it.

This brings us to the thorny but essential question of how to distinguish between an ideological and non-ideological penetration of social relations in general by military relations. At first glance, to maintain this distinction seems to imply an incredible and naïve arrogance on the part of the scholar. How could we possibly know with certainty, especially in difficult matters of war, whether one instance of violence was ideological and another non-ideological? The short answer, of course, is that we cannot - and neither should we aim to. Fortunately, this is not how the critique of ideology, in its mature application, proceeds. We do not need to adopt a crude distinction between reality and misperception to conduct it. Instead, the idea of distinguishing between an ideological and nonideological penetration of social relations by military relations is intended as a critical device for opening analytic and ethico-political questions, rather than as a classificatory schema. There are at least three levels at which ideology critique of militarism can thereby make a contribution, with each level further complicating the conclusions of the last.

First, an ideology critique of militarism identifies a tendency whereby participation in war or military activity acquires an instrumentality for the subjects involved beyond simply their need to use violence 
to achieve a political goal. Instead of representing "an act of force to compel our enemy to accept our will", in the Clausewitzian formulation, war instead becomes bound up with a variety of other functions which are not implied in this strategic objective. In other words, when these subjects desire military activity, they do not desire it because it is helping them to achieve a strategic objective, but for some other reason. To take an example, a soldier may fight in a war to consolidate an identity of military masculinity, rather than because the war is necessary to achieve a strategic outcome. Again, the purpose of this distinction is not to draw this boundary with certainty, but rather to point out the ways that - in a situation of militarism - war becomes bound up with an array of activities and subjectivities not essential for achieving strategic outcomes.

The benefits of this approach become clear when we apply it to the classic case of the civil/military distinction. Militarism often masks and legitimates the pursuit of organised political violence by manipulating this divide. This could include using the military in humanitarian work, declaring a use of violence as a police action, or indeed framing violence as an effort to guarantee security (which, as both Grassiani and Rodriguez-Hernandez point out in this issue, often blurs the civil/military divide in this way). Alternatively, in the terms of the earlier example, militarism might operate through the claim that military activity is performing a vital civic function: consolidating the masculinity of citizens. However, the appropriate critical gesture here is not to re-draw the civil/military boundary more definitively, in the hope of confining "the military" to its box. In fact, this would simply enable similar militarist manoeuvres in future, since any use of organised political violence beyond these confines would therefore gain legitimacy as "civilian". Rather, the critical invocation of the civil/military divide is intended to reveal the ideological work that is being done, through this very distinction, to legitimate violence.

Second, ideology critique prioritises an interrogation of role of desire in the legitimation of violence. When analysing how a penetration of social relations by military relations is ideological, we should not begin from an analysis of whether, in the objective circumstances, such a resort to violence is truly necessary. Leaving aside the difficulty of making such a judgement, this would also be to miss the point. An act of violence can contain within it both strategic and non-strategic instrumentalities (for 
example, it can both reinforce military masculinity and achieve a political objective). The truth or falsity of its strategic necessity is therefore not the crucial question. Rather, we should ask what makes this use of violence desirable to the subject who participates in it. In his psychoanalytic reconstruction of the concept, Žižek explains that the most important dimension of ideology is not the truth or falsity of the beliefs which make it up. Rather, it is our subjective engagement which is the essential dimension of its efficacy: the way that certain beliefs - true or false - entice the desiring subject into continued participation (Žižek, 2012: 8). These beliefs may be true, but it is not their truth which determines the subject's behaviour. The soldier may correctly believe that he is fighting a necessary war, but in a situation of militarism that is not why he fights (for example, he fights because this is the means to consolidate his masculine identity). The critique of militarism as ideology is therefore more sophisticated than a straightforward distinction between "good" and "bad" instances of violence. It asks us to consider why we really want to fight.

Thirdly, ideology critique concentrates on the ways in which this very distinction between "ideological" and "non-ideological" violence, inappropriately deployed, can itself be instrumental in the ideological legitimation of military activity. As Žižek (2012: 4) maintains, the claim to be acting non-ideologically often represents the strongest manifestation of ideology - and this is a claim which militarism frequently makes. Wars are often presented as necessary or unavoidable in order to legitimate them. Moreover, this aura of necessity is often required to activate and consolidate the other components of militarist desire. To return to our example, the soldier who fights in a war because it will help him consolidate a masculine identity may depend on a belief in the necessity of using force (which may well be correct) in order for this militarist consolidation of his masculine identity to take effect. Indeed, this is the myth of the "just warrior" which Jean Bethke Elshtain described (1995: 3-13). A psychoanalytic perspective holds that ideological desires rest implicitly on the idea of an illusory non-ideological kernel of "need" to function (Tomšič, 2015: 117-125). The capitalist desire to accumulate rests on the fantasy that the capitalist is simply engaged in meeting needs through the production of use values. Sexual desire rests on the fantasy that it is derivative of a primordial (and inexistent) sexual relation designed for procreation. Likewise, militarist desire rests 
on the fantasy of a necessary or unavoidable war. Furthermore, militarist ideology can even tolerate the acknowledgement of certain self-evidently ideological elements as long as the fantasy of this "non-ideological" kernel remains intact: yes, our soldiers may fight because they want to consolidate their masculinity, but ultimately the war they are fighting in is necessary. Instead, against this sleight of hand, the critique of militarism as ideology challenges the accepted boundary between "ideological" and "non-ideological" violence, pointing out the ways in which this production of a supposedly "non-ideological" kernel to war is itself internal to militarist ideology.

Therefore, while each of the above three levels of critique rest on the distinction between an ideological and non-ideological penetration of social relations by military relations, they do not do so in order to draw this distinction neatly or definitively. Rather, the critique of militarism as ideology seeks primarily to analyse the conditions in which war and military activity become desirable. While it holds firm to the distinction between ideology and non-ideology, it does so with cautious and critical intent. The advantages of this position are further underscored when we compare the results of an alternative perspective on the critique of violence, one which begins from the concept of "security".

\section{III: Militarism, Critical Security Studies, and the critique of violence}

Recent engagement with questions of violence has been concentrated in the sub-field of IR known as Critical Security Studies (CSS). All scholars working in this tradition see problems with the way that security has been traditionally understood and practised. However, CSS is commonly divided into two sets of approaches: those which aim to reform the concept of security for progressive purposes; and those which aim to move away from the logic of security either partially or wholesale. The first set of approaches has been exemplified by those seeking to redefine security as "emancipation" (Booth, 1991, 2007; Wyn Jones, 2005), and more recently by cosmopolitan theorists seeking to systematise the ethical basis for security practices (Burke et al., 2014, 2016). The second set of approaches includes the Copenhagen and Paris Schools and some feminist, post-colonial, and Marxist approaches, which together broadly share the aim of the "desecuritisation" of politics on the grounds that security 
tends towards exclusionary, emergency, or violent political modalities (e.g. Aradau, 2004; c.a.s.e. collective, 2006; Neocleous, 2008; Reid and Dillon, 2009; Waever, 1995).

The major point of contention between the two tendencies within CSS is therefore whether security can be reclaimed for progressive ends. The desecuritisation critique cautions that any attempt to positively reformulate the concept risks embellishing and thus further legitimating traditional and problematic approaches to security rather than fundamentally re-organising them. In response, defenders of the concept of security charge such criticisms with pessimism and with abandoning the crucial terrain of security to the powerful (Booth, 2007: 163-169; Burke et al., 2014: 43-45, 175176). Moreover, they have proposed several ethical safeguards to avoid the dangers highlighted by their critics. The debate has reached something of an impasse as a result, prompting some to call the future of the sub-field into question (Browning and McDonald, 2013). What can the concept of militarism as ideology add to this debate? In my view, while the desecuritisation critique is potentially powerful, it falls short in large part because it fails to develop a full concept of militarism.

References to militarism and militarisation are quite rare in CSS (Stavrianakis and Selby, 2013: 911). Indeed, discussions of the military dynamics at play in securitisation tend to reveal an absence or under-theorisation of the concept. Most scholars seem to prefer "militarisation" to militarism (a distinction to which I will return), by which they mean the process by which an issue becomes a military concern. For example, in his seminal piece outlining securitisation theory, Waever asks:

"Is it a good idea to frame as many problems as possible in terms of security? Does not such a strategy present the negative prospect of, in a metaphorical sense, militarising our thinking and seeing problems in terms of threat-vulnerability-defence, when there are good reasons for not treating them according to this formula?" (Waever, 1995: 64-65)

Likewise, Didier Bigo warns that security tends to produce "a 'war-based polity', a condition of generalized confrontation that is no longer able to distinguish between private and public enemies" (Bigo, 2002: 81). Other oblique references to militarisation in this literature highlight the process whereby an issue is turned into a concern of the military institutions and/or coercive apparatuses of 
the state (c.a.s.e. collective, 2006: 461; see also Bigo, 2002: 63, 76-77). The critical import behind these suggestions seems to be that security gives rise to militarisation, and that militarisation is something to be avoided either because it unhelpfully frames issues as threats or because it hands the initiative to the state.

In the feminist literature, much greater analytic and political clarity can be found (for more detail, see Wibben in this issue). For example, the path-breaking work of Cynthia Enloe, which has inspired much of feminist CSS, is guided by an ambition to "demilitarise" and move away from the culture of national security. She also gives explicit definitions of militarism and militarisation (2007: 1-14). Yet the scope of her ambition is still left somewhat unclear. Enloe defines militarism as "a complex package of ideas that, together, foster military values in both military and civilian affairs [...which] justifies military priorities and military influences in cultural, economic, and political affairs" (2007: 11), but she goes on to give a list of militarist ideas which is non-exhaustive and wide-ranging, including preferences for: hierarchy, patriarchical protection, state militaries and the use of force. Her concept of militarisation, defined as "the step-by-step [...] process by which any person, any group, or any society absorbs the ideas and resultant practices of militarism" (2007: 11), seems closer to my account and helpfully draws our attention to everyday social processes (2007: 68-69; Wibben, this issue). However, this definition still seems to be dependent on the earlier notion of positively-held militarist ideas which act as a kind of checklist for discerning militarisation (see also Enloe, 2016). It remains unclear, firstly, whether militarism and militarisation are problematic chiefly because of the effects of these specific ideas, or for some more fundamental reason going beyond them, and secondly, whether or not "demilitarisation" has to imply pacifism.

The range of CSS literatures calling for desecuritisation therefore do not yet offer a full account of militarism as I have elaborated it above, in which organised political violence is made desirable through ideology and thereby loses strategic impetus and restraint. This is important because it has also shaped the response of those seeking to reclaim security against these critiques. Revealingly, these responses tend either to reject the call for desecuritisation as too pacifist or to develop safeguards against the specific effects that these critics identify with "militarisation", rather than 
engaging with the underlying ideological nature of militarism. While this has certainly left their analysis wanting too, and reveals an equally unsatisfactory conceptualisation of militarism, it also shows the limitations and vulnerability of CSS arguments calling for desecuritisation.

For example, Booth argues that security should only ever be the "means" for the "end" of emancipation (2007: 114-115) and that means and ends should be related "non-dualistically" (i.e. the means should be consistent with the ends sought) (2007: 428-441). He explicitly includes political violence as a means which must be subject to this rule (2007: 429-431) and he even embraces aspects of Gandhian non-violence (Booth, 2007: 115). Discussing the critique offered by securitisation theory, he responds "we would all presumably agree that the unnecessary securitisation (militarisation) of issues is to be deplored, but there are occasions when introducing a military dimension is sensible" (2007: 168). Booth's ethical criteria for the use of force therefore give him the confidence to respond that not all militarisation is a bad thing, and that it can be used for progressive ends. What is notable here is that Booth also invokes a thin notion of "militarisation", more or less reducible to the decision to use force, to establish his claim. He is quite comfortable with the risks of militarisation identified by securitisation theory because he believes he has circumvented them. By contrast, the critique of militarism as ideology gives us more powerful tools to disagree with Booth here. For Booth ignores the danger that, in conditions of militarism, war can begin to serve a wide array of non-strategic instrumentalities as a result of its ideological penetration of social relations. Militarism can entrench a pattern of conflict by binding social relations, subjectivities, and identities to the pursuit of war, thereby making war far less amenable to ethico-political discipline than he imagines. By setting up emancipation as an imperative which must be "secured", including militarily, Booth opens a dangerous pathway to the entrenchment of violence.

Responding to critiques of securitisation in their cosmopolitan approach, Burke, Lee-Koo, and McDonald are more sensitive to these dangers, admitting that the use of force can entrench conflict and thus impair the longer term pursuit of global security (Burke et al., 2014: 19-21). In response, they argue that the ultimate aim of security practice should always be non-violence, "a gradual but determined demilitarisation of global politics" in which force is permissible under strict conditions but 
always regrettable - "a pacifism of ends rather than means" (Burke et al., 2016: 74). They place their confidence in a set of detailed principles restricting the use of force in different circumstances, which they hope will help to avoid these risks (Burke et al., 2014: 71-97, 119-145). Again, however, the ambition for non-violence rests on the thin basis of an aspiration for "demilitarisation", something which they in fact derive from the critique of securitisation, rather than an understanding of militarism as ideology. As I have explained above, what characterises militarism is not violence with a lack of a true justification but an ideological desire for war and military activity. Militarism is therefore fully compatible with a credible justification for violence, and may even draw strength from it. Burke, LeeKoo and McDonald's criteria for the use of force may well be stricter than available alternatives, therefore, but this is still no guarantee against militarism. Even if they succeeded in preventing some wars, they would still not ensure that the remaining, apparently justified wars did not indulge in and encourage militarism. Cosmopolitan theories therefore do not disrupt the ideological factors making war desirable; rather, they risk supplementing them with additional justifications. A more effective critical intervention against cosmopolitan security is therefore to highlight the dangers of militarism as ideology, rather than simply to call for demilitarisation.

\section{Conclusion}

What the above arguments stress is the importance of embracing a critical concept of militarism, one premised on the explicit ambition to disrupt its ideological effects. With this in mind, it is worth considering why most CSS scholars prefer to adopt the term "militarisation" rather than militarism. Militarisation in this usage seems to imply the process of making something a military concern. In this way it is similar to Shaw's account, in which militarisation implies an increase in the penetration of social relations in general by military relations - or, in other words, the process by which more and more things are made military concerns. For Shaw the concept of militarism functions as a measure of this penetration. But this is not the same as a critical concept of militarism, in which the specific kind of penetration being analysed is an ideological penetration and in which the intention is to disrupt this penetration through critique. Like Shaw, CSS has also understood militarism as a measure (of 
"militarisation") rather than as a critical concept, with the result that its analytic and political potential has been blunted when engaging in the critique of violence.

However, this may also be a reflection of an underlying tendency in CSS itself. For we could argue that neither are "security" or "securitisation" critical concepts in the sense intended by ideology critique. Instead, they are more like measures, in that they measure either how secure something is or how securitised an issue has become. One consequence of this, which is particularly problematic for scholars seeking desecuritisation, is that these concepts therefore also actively participate in the process they seek to critique: they name things as "security" issues, even when the argument is that these issues should not be security issues at all. This proliferation of security concerns, encouraged as much by scholarship as by practitioners, results in the "crowding out" of other frameworks which may more accurately reflect the underlying dynamics - concepts such as war (Barkawi, 2011) or neoliberalism (Montesinos Coleman and Rosenow, 2016) - and which may be more appropriate for critical ethico-political interventions into phenomena that CSS interprets as security or securitisation. My final suggestion is that militarism is yet another concept which risks being obscured in CSS analysis by this tendency to measure rather than critique. By contrast, I have shown above how a more critical concept of militarism as ideology can offer a superior starting point for an analysis of the shortcomings of various justifications for the use of force, including those encountered in CSS. Militarism can help us to think more precisely about the circumstances in which the use of violence to achieve political objectives (such as "security") can descend into a more generalised and intractable desire for war and military activity. My hope is that from such an understanding we might also better equip ourselves to intervene in this process and resist it.

\footnotetext{
${ }^{1}$ In this article I use the terms "violence", "war", and "military activity" interchangeably to mean "the preparation for, and conduct of, organised political violence" as outlined by Stavrianakis and Selby in their definition of militarism (2013: 3).
} 


\section{References}

Althusser L (1971) Ideology and Ideological State Apparatuses. In: Lenin and Philosophy and Other Essays, Monthly Review Press, pp. 121-176.

Altınay A (2004) The myth of the military nation: militarism, gender, and education in Turkey. New York: Palgrave Macmillan.

Aradau C (2004) Security and the democratic scene: desecuritization and democratization. Journal of International Relations and Development 7(4): 388-413.

Barkawi T (2011) From war to security: security studies, the wider agenda and the fate of the study of war. Millennium: Journal of International Studies 39(3): 701-716.

Barkawi T and Brighton S (2011) Powers of war: fighting, knowledge, and critique. International Political Sociology 5(2).

Basham V (2016) Raising an Army: The Geopolitics of Militarizing the Lives of Working-Class Boys in an Age of Austerity. International Political Sociology.

Bigo D (2002) Security and immigration: towards a critique of the governmentality of unease. Alternatives: Global, Local, Political 27(1): 63-92.

Booth K (1991) Security as emancipation. Review of International Studies 17(4): 313-326.

Booth K (2007) Theory of World Security. Cambridge: Cambridge University Press.

Browning C and McDonald M (2013) The future of critical security studies: ethics and the politics of security. European Journal of International Relations 19(2): 235-255.

Burke A, Lee-Koo K and McDonald M (2014) Ethics and Global Security: A Cosmopolitan Approach. Oxford: Routledge.

Burke A, Lee-Koo K and McDonald M (2016) An Ethics of Global Security. Journal of Global Security Studies 1(1): 64-79.

c.a.s.e. collective (2006) Critical Approaches to Security in Europe: A Networked Manifesto. Secuirty Dialogue 37(4): 443-487.

Cockburn C (2012) Antimilitarism: Political and Gender Dynamics of Peace Movements. London: Palgrave Macmillan.

Conway D (2012) Masculinities, Militarisation, and the End Conscription Campaign: War Resistance in Apartheid South Africa. Manchester: Manchester University Press.

Crane-Seeber J (2016) Sexy warriors: the politics and pleasures of submission to the state. International Political Sociology 2(1-2): 41-55.

Elshtain J (1995) Women and War. second edition. Chicago: University of Chicago Press.

Enloe C (2000) Maneuvres: The International Politics of Militarising Women's Lives. Berkeley: University of California Press.

Enloe C (2007) Globalization and militarism : feminists make the link. Lanham: Rowman and Littlefield. 
Enloe C (2016) How can you tell if you are becoming militarized? Doing a feminist audit. Talk at the University of Westminster, $22^{\text {nd }}$ September 2016. Available from:

https://www.youtube.com/watch?v=yTuSCKVwGlA.

Hallward P and Peden K (eds) (2012) Concept and Form, Volume I: Key Texts from the Cahiers pour l'Analyse. London: Verso.

Higate P (2012) The private militarised and security contractor as geocorporeal actor. International Political Sociology 6.

Hutchings K (2007) Feminist ethics and political violence. International Politics 44: 90-106.

Mann M (1987) The Roots and Contradictions of Modern Militarism. New Left Review 162.

McSorley K (2013) War and the Body: Militarisation, practice, and experience. Oxford: Routledge.

McSorley K (2016) Doing military fitness: physical culture, civilian leisure and militarism. International Political Sociology 2(1-2): 103-119.

Montesinos Coleman L and Rosenow D (2016) Security (studies) and the limits of critique: why we should think through struggle. Critical Studies on Security.

Neocleous M (2008) Critique of Security. Edinburgh: Edinburgh University Press.

Reid J and Dillon M (2009) The Liberal Way of War: Killing to Make Life Live. Oxford: Routledge.

Rossdale C (2010) Anarchy is what anarchists make of it: reclaiming the concept of agency in IR and security studies. Millennium: Journal of International Studies 39(2): 483-501.

Rossdale C (2015) Enclosing critique: the limits of ontological security. International Political Sociology 9: 369-289.

Sasson-Levy O (2003) Constructing Identities at the Margins: Masculinities and Citizenship in the Israeli Army. The Sociological Quarterly 43(3).

Sasson-Levy O (2008) Individual bodies, collective state interests: the case of Israel combat soldiers. Men and Masculinities 10(3).

Segal L (2008) Gender, war and militarism: making and questioning the links. Feminist Review 88.

Shaw M (1991) Post-Military Society: militarism, demilitarisation, and war at the end of the twentieth century. Temple University Press.

Shaw M (2013) Twenty-first century militarism: a historical-sociological framework. In: Stavrianakis A and Selby J (eds), Militarism and International Relations: Political Economy, Security, Theory, Oxford: Routledge.

Sjoberg L and Via S (eds) (2010) Gender, War, and Militarism: Feminist Perspectives. Santa Barbara: Praeger.

Skjelsbaek K (1980) Militarism, its dimensions and corollaries: an attempt at conceptual clarification. In: Eide A and Thee M (eds), Problems of contemporary militarism, London: Croom Helm.

Stavrianakis A and Selby J (2013) Militarism and International Relations in the 21st century. In: Stavrianakis A and Selby J (eds), Militarism and International Relations: Political Economy, Security, Theory, Oxford: Routledge. 
Sylvester C (2012) War Experience/War Practices/War Theory. Millennium: Journal of International Studies 40(3): 483-503.

Tomšič S (2015) The Capitalist Unconscious: Marx and Lacan. London: Verso.

Vagts A (1959) A history of militarism: civilian and military. second edition. New York: Meridian Books.

Waever O (1995) Securitization and Desecuritization. In: Lipschutz R (ed.), On Security, New York: Columbia University Press, pp. 46-86.

Wyn Jones R (2005) On emancipation: necessity, capacity, and concrete utopias. In: Booth K (ed.), Critical Security Studies and World Politics, Boulder: Lynne Rienner, pp. 215-236.

Žižek S (2008a) The Plague of Fantasies. second edition. London: Verso.

Žižek S (2008b) The Sublime Object of Ideology. second edition. London: Verso.

Žižek S (2008c) The Ticklish Subject: The Absent Centre of Political Ontology. second edition. London: Verso.

Žižek S (ed.) (2012) Mapping Ideology. London: Verso. 